\title{
Comparison of in situ nylon bag technique with in vitro procedure to estimate dry matter and other nutrients digestibility in buffalo calves
}

\author{
Om Prakash
}

\begin{abstract}
Three male murrah buffalo calves were taken for entire investigation. The average digestibility co-efficient for dry matter, crude protein, ether extract, crude fibre, nitrogen-free extract, total carbohydrates, total ash, acid detergent fibre and neutral detergent fibre were $53.05 \pm 11.05,54.50 \pm 0.90,52.59 \pm 11.14,53.54 \pm 1.09,53.38 \pm 1.04,53.38 \pm 1.08,32.08 \pm 2.04,52.82 \pm 1.60$ and $60.06 \pm 1.19$ at 72 hours, respectively by in situ nylon bag technique. The average digestibility of above mentioned feed nutrients were recorded to be $52.19 \pm 1.03 \%, 53.09 \pm 1.04 \%, 51.39 \pm 1.09 \%, 52.41 \pm 1.07 \%, 52.56 \pm 0.99 \%, 52.43 \pm 1.06,31.61 \pm 1.90 \%$, $51.88 \pm 1.07 \%$ and $59.09 \pm 1.17 \%$ at 72 hours, respectively by in vitro procedure. The dry matter, crude protein and ether extract digestibility estimated by in situ nylon bag technique were significantly higher $(\mathrm{P}<0.01)$ than the value estimated by in vitro procedure. The crude fibre, nitrogen-free extract, total carbohydrates, total ash and neutral detergent fibre digestibility values obtained by in situ nylon bag technique vs. in vitro procedure did not differ significantly. The acid detergent fibre digestibility was statistically significant $(\mathrm{P}<0.05)$ in in situ nylon bag technique than in vitro procedure.
\end{abstract}

KEY WORDS : Comparison, Nylon bag, In vitro, Digestibility, Dry matter

HOW TO CITE THIS PAPER : Prakash, Om (2018). Comparison of in situ nylon bag technique with in vitro procedure to estimate dry matter and other nutrients digestibility in buffalo calves. Res. J. Animal Hus. \& Dairy Sci., 9(1) : 1-7 : DOI: 10.15740/HAS/RJAHDS/9.1/1-7. Copyright@ 2018: Hind Agri-Horticultural Society. 